\title{
ダイシングテープの要求特性と開発動向
}

\author{
高 橋 和 弘
}

\section{Requirements and Development Trend of Dicing Tapes}

\begin{abstract}
Kazuhiro TAKAHASHI (LINTEC Corporation, 5-14-42 Nishikicho, Warabi-shi, Saitama 335-0005, Japan)
\end{abstract}
Dicing tapes have been used for a Si wafer singulation at the IC packaging manufacturing. During the singulation, dicing tapes need to hold dies with high adhesion simultaneously with an easy die separation from the dicing tapes with low adhesion after singulation to prevent dies from breaking.In order to meet the requirements mentioned above, UV-curable dicing tapes, which is reviewed here, have been realized with both die-holding and easy-separation functions which are able to be controlled, independently. Moreover, with the popularity of the mobile devices, a packaging density and a die thickness tend to increase and decrease, respectively. For a reduction of thin wafer breaking, new thin-wafer processes, including a laser-dicing process, have been proposed and dicing tapes are required to have additional properties to realize those thin wafer processes. In this paper, the technical trend of dicing tapes for the new applications is presented.

Key Words : Semiconductor,Wafer,Dicing,Adhesive,Tape

\section{3. ダイシングテーブ}

\section{1. は じめ に}

スマートフォンやタブレット端末に代表される携帯型の 通信機器は, 高性能化と並行して薄型化, 軽量化が期待さ れている。そのため機器内部に搭載されるICパッケージ の高密度化が追求され, 半導体回路パターンの微細化はも とより, ICパッケージ内で複数のチップを積層する三次 元実装が害用化されている．三次元実装ではチップの薄型 化 ${ }^{1)}$ が技術基盤となるため, 薄型チップを安定生産可能 なプロセス開発と，それを実現するための材料開発が重要 となっている．本稿では近年ダイシングテープに要求され る性能と開発動向について紹介する.

\section{ICパッケージの生産プロセス}

シリコンを円柱状に結晶化させたインゴットから 600 $800 \mu \mathrm{m}$ 程度の厚さにシリコンウェハがスライスされる. このウェハ上に電子的な回路が形成される. 回路が形成さ れたウェハは図1に示すプロセスを経て IC パッケージへ 加工される. ウェ八は回路面の裏面を研削され，要求され る厚さに仕上げられたウェハはダイシングテープ上に固定 され，ブレードによって個々のチップに分割される，分割 されたチップは一つずつピックアップされてインターポー ザに実装され，エポキシ樹脂等で封止されて ICパッケー ジへ加工される.

\section{1 ダイシングテープの形態}

ダイシングテープの形態は大きく 2 種類に大別される. 一方は基材と粘着剤のみから構成されるタイプ，もう一方 は基材と粘着剤の他にはく離フィルムが積層されたタイプ である。はく離フィルムはウェ八貼付直前まで粘着剤表面

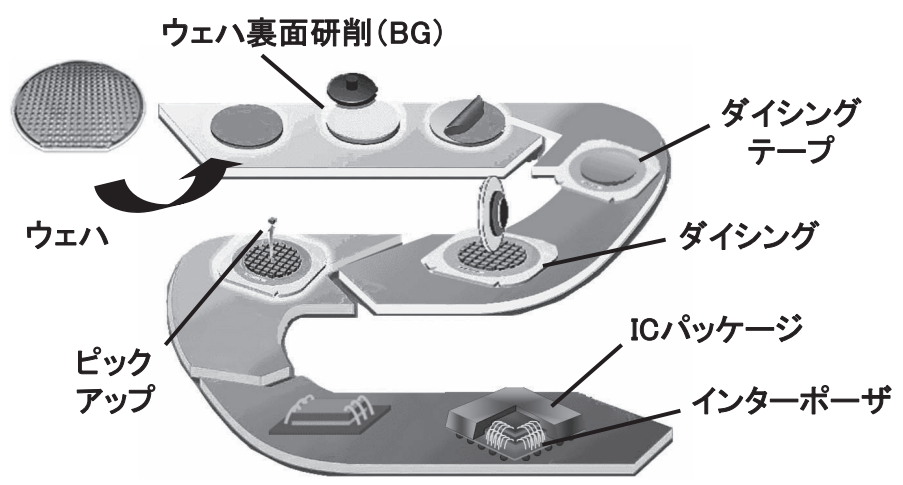

図1 ICパッケージの製造プロセス

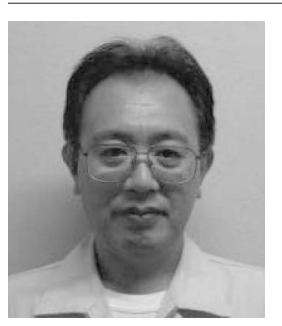

高橋 和弘；リンテック侏）技術統括本部研 究所製品研究部 電子. 光材料研究室 ( ₹ 3350005 茨市錦町 5-14-42). 平成元年, 東京理科 大学理学専攻科化学専攻修了. 同年, リンテ ック秼入社，現在に至る。専門は，粘着・接 着製品の研究開発. 
を保護する目的で用いられるＩCチップの加工用途で用 いられるダイシングテープは, 粘着剤表面の污染を嫌い, さらにその平滑性が重視されるためコストで有利な前者よ り後者が主流となっている．防塵性を考慮して基材とはく 離フィルムにはプラスチックフィルムが用いられる.ダイ シングテープはウェハの回路が形成されていないウェハ裏 面に貼付され，同時に支持・搬送用のステンレス製リング フレームにマウントされて使用される。そのためリングフ レーム径に合わせて，あらかじめラベル状に加工されたプ リカット形状での供給形態が一般化している．ウェハをリ ングフレームにマウントした後, リングフレーム上でダイ シングテープをカットする工程が不要となるプリカット供 給は，発塵を嫌う半導体プロセスでは有利といえる．ダイ シングテープの外観（ロール供給とプリカット供給）およ びリングフレームへマウントされたウェハの写真を図 2 に 示す.ダイシングテープは異物混入や污染に配慮して専用 のクリーン環境設備で生産される.

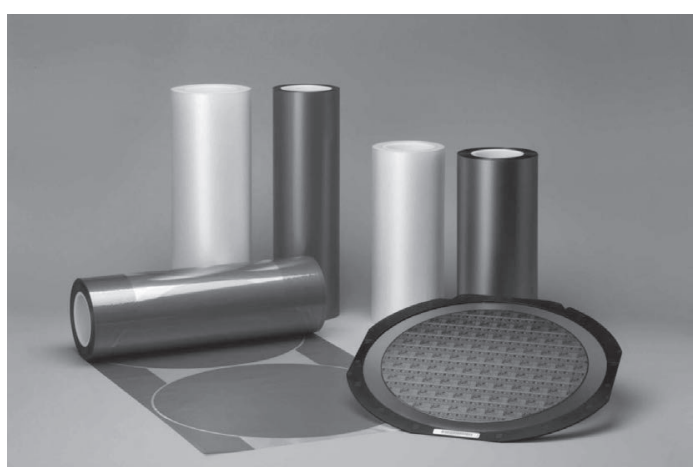

図2 ダイシングテープ外観写真
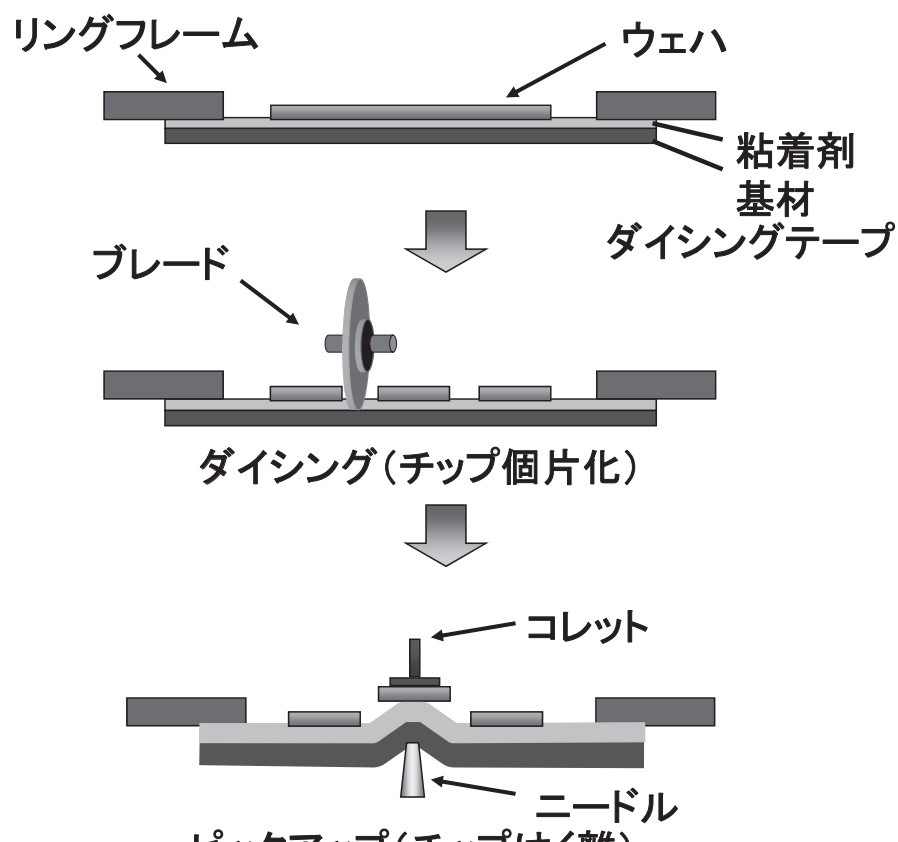

ピックアップ（チップはく離）

図3 ダイシングテープが使用される工程
3.2 ダイシングテープに要求される性能

3.2.1 ダイシングテープが使用される工程

ダイシングテープは回路が形成された半導体ウェハを 個々のチップに分割するダイシング工程のみならず，分割 されたチップをピックアップ（図3）してインターポーザ ヘマウントするダイボンディング工程まで継続して使用さ れる。

\subsection{2 ダイシングテープに要求される性能}

ダイシングテープに要求される基本性能を以下に列挙す る.

(1)ダイシング時は十分な粘着力でウェハおよび分割され たチップを固定できること。

(2)ダイシング時の高速回転ブレードによる切削抵抗に耐 え，チップの位置ずれや飛散を発生しない十分な保持 力を有すること.

(3)ダイシングによって発生するテープの切断屑が実用領 域であること。

(4)ピックアップ時にはチップを破損することなく，容易 にチップをはく離できること。

(4)チップ裏面への粘着郕転着が僅少であること.

\subsection{3 ダイシングテープ用基材}

ダイシングテープの基材には，軟質ポリ塩化ビニル，ポ リエチレンやポリプロピレンなどのポリオレフィン，それ らに異種物質を共重合または混合した変性ポリオレフィ ン，PETなどのポリエステルフィルムが使用される。ポ リ塩化ビニルに可塑剤を添加した軟質ポリ塩化ビニルを基 材に使用したダイシングテープは，製造からの経過時間と ともに可塑剤が粘着剤へ移行するケースが多く，粘着物性 が不安定になりやすい.さらにポリ塩化ビニルとその可塑 剂として広く使用されるフタル酸エステルはいずれも環境 問題の側面を抱えているが，安価なこととその使い勝手に

\section{切断首}

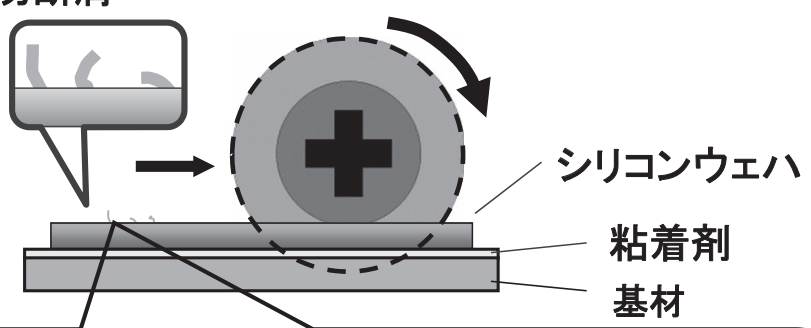

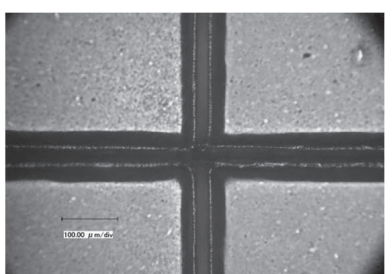

切断屑なし

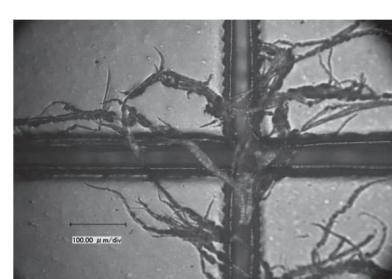

切断居発生 
優れていることから減少傾向ではあるが，現在でもなお使 用されている。

ダイシング工程ではウェハを完全に分割できるようにブ レード高さが設定されるため，ブレードによる切达みはダ イシングテープにまで到達する．このときダイシングテー プから発生する切断屑がチップ污染の原因となる（図4). 切断屑の発生は主に基材材質に起因しており，ダイシング 時の摩擦熱によって溶融した基材原料の粘度とある程度相 関する。そのため切断屑の発生に配慮した基材原料の選定 が重要となる。

\subsection{4 ダイシングテープ用粘着凧}

3.2.2 項の (1)，(2)と(4)は二律背反の性能である。一般の粘 着剂を使用したダイシングテープでは，小さいサイズのチ ップがダイシング時に飛散しやすく，逆に大きいサイズの チップはピックアップ時にはく離不良を生じる不具合等が 発生しやすかった。

そこでこれらの要求性能を実現するために強力な固定能 と易はく離能を兼備したUV硬化型粘着剤が開発された。 ここで本稿ではUV硬化前の粘着力およびUV 硬化 後の粘着力が，それぞれ独立して制御可能な粘着剤 をUV 硬化型粘着剤と定義する．現在ではダイシン グ後，チップをピックアップする前にダイシングテ ープにUVを照射することで粘着剤を硬化させ，粘 着力を低下させるとともに粘着剤転着を僅少に抑制 したUV硬化型ダイシングテープが一般化している.

\subsection{UV 硬化型粘着剤}

$\mathrm{UV}$ 硬化型粘着剤の多くはアクリル酸エステル共 重合体とUV硬化性樹脂のブレンド型であり，多数 の特許 ${ }^{2-4)}$ が報告されている.UV硬化による粘着 力低下機構を図 5 に示す. UV 硬化による粘着力低 下の主たるメカニズムは，UV硬化性樹脂の光ラジ カル重合による三次元網状化で生じる粘着剂の弾性 率上昇（常温域では $10^{5} \mathrm{~Pa}$ 程度から $10^{9} \mathrm{~Pa}$ 程度へ上 昇）と体積収縮である。

ここでUV硬化成分として 3 官能アクリルモノマ ーおよび6官能アクリルモノマー（図6）をアクリ ル酸エステル共重合体にそれぞれ重量比 $1: 1$ でブレ ンドした場合のUV硬化前後の粘着力と粘着剤弾性 率（表1）とチップはく離挙動を紹介する.

ダイシングによって個片化されたチップのピック アップ工程は図 3 に示したようにダイシングテープ 越しにチップの裏面をニードルで突き上げ，チップ の回路面をコレットで減圧吸着し，チップをテープ からはく離する。はく離はテープの変形をともない ながらチップ四辺からチップ中央に向かって進行す る.

図7にピックアップ工程でダイシングテープから
チップがはく離されるまでの時間と突き上げニードルに加 わる荷重（ピックアップ力）の関係を示す．突き上げ初期 は時間の経過とともにニードルに加わる荷重は上昇する. これはダイシングテープを変形させるためにニードルに加 わる荷重であり，ダイシングテープに使用される基材の曲 げ剛性とほぼ相関する。ニードルに加わる荷重がピーク值 を示す点がチップの四辺でテープのはく離が開始する点で あり，また急激に低下する点がはく離完了点である．3官 能アクリルモノマーをブレンドした場合，ピーク值は低い がその後はく離完了までに時間を要する，UV硬化後の粘 着剂弾性率の上昇が低いため，はく離のきっかけとなるチ ップ四辺での粘着剂変形は起こりやすいが，粘着力が十分 に低下しないためはく離の進行は低速となる．逆に6官能 アクリルモノマーをブレンドした場合はUV硬化後の粘着 剂弾性率上昇が高く，はく離のきっかけとなるチップ四辺 での粘着剂変形に荷重を要するが，粘着力が十分低下して いるためはく離の進行は高速となる，薄型化されたチップ は非常に脆弱であり，破損なくピックアップするためには
(1) 弾性率上昇

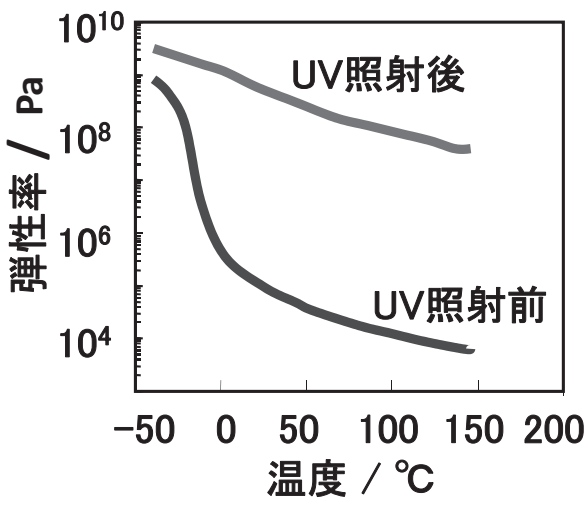

(2) 体積収縮

Si wafer 㭗亲剂

\section{UV照射}

Si wafer

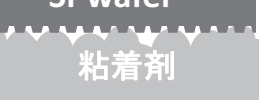

図 5 UV 照射による粘着力の低下機構

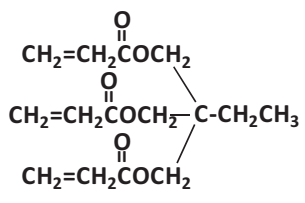

3官能アクリルモノマー Trimethylolpropane triacrylate (TMPTA)

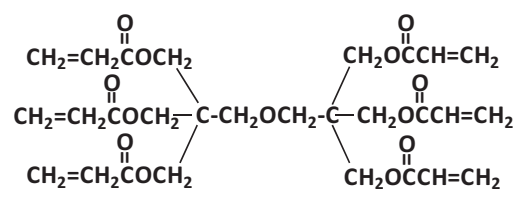

6官能アクリルモノマー Dipentaerythrytol hexaacrylate (DPHA)
図6 重合性アクリルモノマー

表1ＵV硬化型粘着剤の粘着力と弾性率

\begin{tabular}{c|c|c|c|c}
\hline \multirow{2}{*}{ UV 硬化成分 } & \multicolumn{2}{|c|}{ 粘着力 */mN } & \multicolumn{2}{|c}{ 弾性率 $/ \mathrm{MPa}$} \\
\cline { 2 - 5 } & $\mathrm{UV}$ 照射前 & $\mathrm{UV}$ 照射後 & $\mathrm{UV}$ 照射前 & $\mathrm{UV}$ 照射後 \\
\hline Blank & 4200 & - & 0.39 & - \\
\hline 3 官能 & 1000 & 570 & 0.33 & 27 \\
\hline 6 官能 & 1400 & 110 & 0.08 & 200 \\
\hline \multicolumn{4}{|c}{} & \multicolumn{3}{|c}{ *サプル幅 $: 25 \mathrm{~mm}$}
\end{tabular}


ピックアップ時のピーク荷重とはく離時間をできるだけ低 減させてチップに与えるダメージを抑制することが重要で ある。

$\mathrm{UV}$ 硬化性樹脂のブレンド型粘着剤は設計の多様性から 目的に応じたさまざまな粘着特性を発現するのに有利であ るが，原材料の相溶性に十分な配慮がなされないと相分離 によって誘発されるウェハ（チップ）污染が懸念される。 最近ではラジカル重合性二重結合をアクリル酸エステル共 重合体中に導入し，組成物全体を高分子量化させることに よって污染に対して信頼性の高い反応性ポリマーも開発さ $れ^{5-6)}$ ，実用化されている7).

\section{4 ウェハ薄型化にともなう問題点}

\subsection{1 チップクラック}

ウェハ薄型化にともないダイシング時に発生するチップ クラックが問題視されるようになった。薄型ウェハではチ ップ強度にクラックが著しく影響を与えるためである ${ }^{8)}$. UV 硬化前（ダイシング時）粘着剤弾性率とチップクラッ ク数の関係を図 8 に示す。薄型ウェハ用ダイシングテープ の粘着剤は，UV硬化前の特性としてチップクラックを抑 制した弾性率，UV硬化後の特性としてピックアップカピ ーク值の低減とチップはく離時間の短縮，そのすべてに配 慮して設計される.ダイシングとピックアップ，それぞれ の工程に対してそれぞれ最適な粘着力と弾性率に制御し,

かつ活染を僅少に抑制することで高品質なチップが効率的 に生産可能となる。

\subsection{2 ウェハ活性面への対応}

従来はダイシングテープ貼付とその前工程のウェハ裏面 研削（バックグラインド）は独立した装置で行われていた. しかしバックグラインド $(\mathrm{BG})$ で薄型化したウェハは脆 弱で装置間，工場間の搬送が困難となり，次工程のダイシ ングテープ貼付までに破損する問題が生じた。そこで BG 直後にインラインでダイシングテープを貼付する工程が提 案され，実用化している（図9）。このプロセス変更はダ イシングテープに新たな課題を提供した。研削直後のウェ 八董面にダイシングテープを貼付した場合，ピックアップ 工程でチップのはく離不良が生じた.

図 10 にウェハ董面研削からの経過日数を変えてダイシ ングテープを貼付した場合のUV照射後粘着力，および経 過日数とウェハ研削面の酸素・ケイ素モル比 $(\mathrm{O} / \mathrm{Si})$ の関 係を示す。粘着力はウェハ裏面研削直後に貼付した場合に 最も高く，経過日数とともに低下した。一方でウェハ研削 面の酸素・ケイ素モル比 $(\mathrm{O} / \mathrm{Si})$ は経過日数とともに上昇 した。研削によって新たに生じた結晶表面は酸化が不十分 でシリコン原子の活性なダングリングボンド（共有結合の 相手を失った反応性の高い結合手) が残存しており，粘着 剂との化学的相互作用が高く, 結果として粘着（はく離） 力が上昇したものと推測される．従来プロセスではウェハ 裏面研削からダイシングテープ貼付までに時間的な猶予が

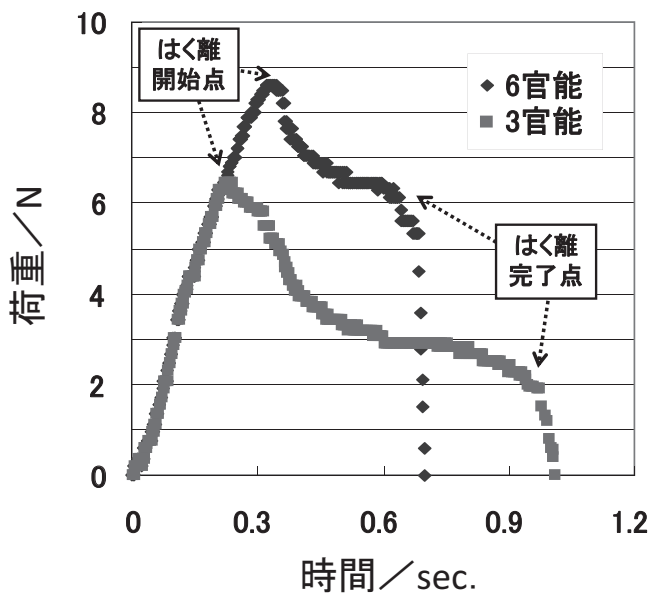

図7 時間とニードル荷重の関係

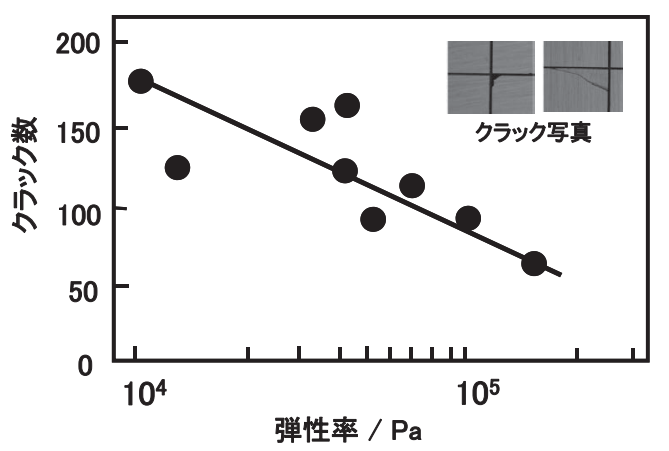

図8 粘着剂弾性率 (UV 照射前) とクラック数の関係

\section{〈従来プロセス〉}

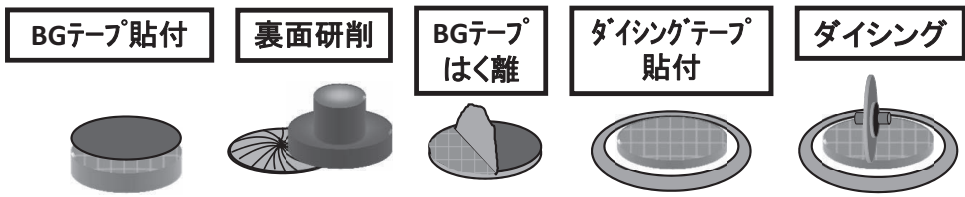

〈薄型化プロセス〉

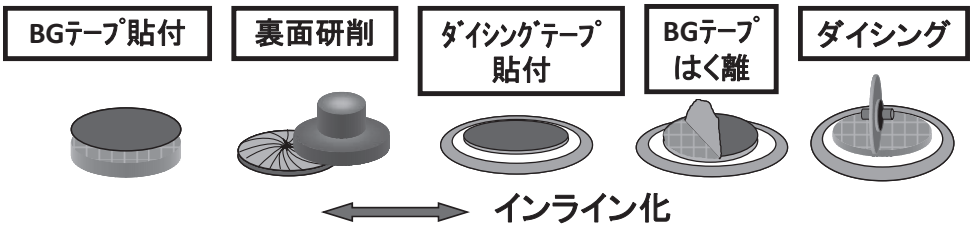

図 9 チップ薄型化に向けたプロセス変更

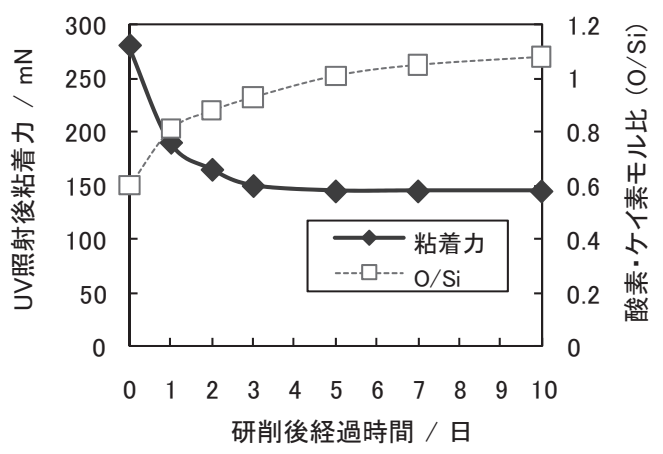

図 10 研削後の時間と粘着力，酸素・ケイ素比の関係 
あり，化学的に安定な酸化膜 $\left(\mathrm{SiO}_{2}\right)$ が研削面に形成され た後にダイシングテープが貼付されていたが，プロセス変 更によってウェハ研削直後の活性裏面にダイシングテープ が貼付されることとなり，ダイシングテープにウェハ活性 裏面との化学的相互作用を考慮した粘着剂設計が必要とな った。

\section{5 レーザダイシング}

\subsection{1 ブレードダイシングの問題点}

チップの薄型化によって従来の機械的なブレードダイシ ングに起因したチップクラックの問題が表面化してきた. また高速・大容量化通信を支える高周波デバイスに使用さ れる化合物半導体（GaAsなど）は脆弱な素材のため，ブ レードを用いたダイシング方法では加工（ブレード送り） 速度を低下せざるを得ず，生産性を高めることが困難であ った。さらに発光ダイオード（LED）の生産量が飛躍的 に増加する中，LED用化合物半導体（GaNなど）を結晶 成長させるための単結晶サファイヤ基板は硬度が高く，ブ レードによるダイシングに課題を残した。

こうした問題を背景にレーザダイシングが注目されてい $3^{9-11)}$ ・レーザダイシングはウェハに非接触なダイシン グ法で，脆弱なウェハに与えるダメージが低く，チップ強 度の低下原因となるクラックが抑制でき，また加工速度の 向上も期待できる.

シリコン単結晶ウェハはおおよそ波長 $1000 \mathrm{~nm}$ を境に してそれより短波長の光を吸収し長波長の光を透過する。 レーザダイシングはウェハに対して吸収性の高い波長のレ ーザをウェハ入射面へ吸収させて蒸散（アブレーション） させるレーザアブレーションダイシングとウェハに対して 透過性となる波長のレーザをウェハ内部に集光させてウェ 八内部に改質層を形成させるステルスダイシングが提案さ れている。

\subsection{2 レーザアブレーションダイシング}

ウェハはその外側の支持用リングフレームとともにダイ シングテープヘマウントされる。ウェハ外周部まで確実に チップを個片化するため，レーザはウェハ上に設計された ダイシングラインを越え, その延長線上のダイシングテー プまで走査される。すなわちダイシングテープに直接レー ザが照射されることとなる（図 11）。

レーザアブレーションダイシングでは照射したレーザの 波長を吸収するダイシングテープは容易にダメージを受け る．逆にレーザを透過するダイシングテープを使用した場 合はテープを透過したレーザによってワーク固定用の吸着 テーブルが高温となることでテープがテーブルに融着し， さらには吸着テーブルを損傷する。 これらの問題を解決す るためダイシングテープに新たな材料設計が必要となっ た。

\subsection{3 レーザアブレーションダイシングテープ}

ダイシングテープ基材として一般的な軟質ポリ塩化ビニ ルフィルム，ポリオレフィンフィルム， PETフィルム， それに融点の高いポリイミドフィルムにそれぞれ波長 355 $\mathrm{nm}$ のレーザを上方から照射した。レーザアブレーション ダイシング用に専用設計されたフィルムとの比較断面図を 図11に示す.

レーザアブレーションダイシングではレーザのエネルギ 一を適度に吸収することで固定用吸着テーブルに与える損 傷を抑制し，かつ自身が完全に切断されないダイシングテ ープの設計が必要である。

\subsection{4 ステルスダイシング12)}

ステルスダイシングは単結晶シリコンに対して透過性の レーザを回折レベルでウェハ内部に集光させ，非線形吸収 効果によってシリコンを多結晶化させ，このとき生じる体 積膨張によってウェハ内部に応力歪 (改質層) を残留させ, ここを起点として外力（テープのエキスパンド）によって

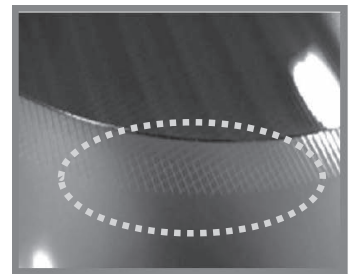

ウェハ外側

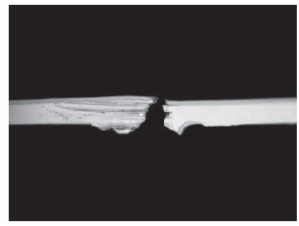

PET

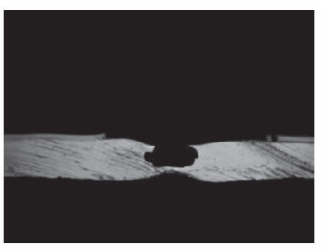

ポリ塩化ビニル ポリオレフイン

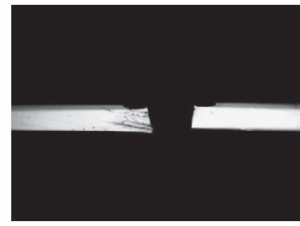

ポリイミド
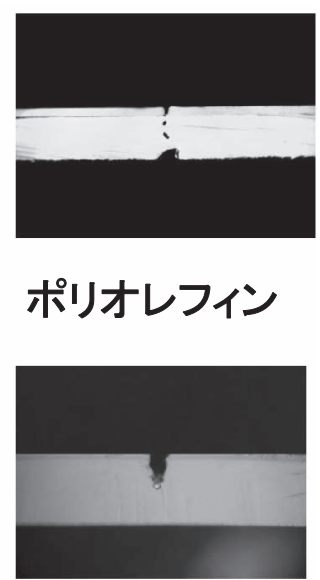

開発品

図11 ウェハ外側のテープダメージと基材の比較断面図 


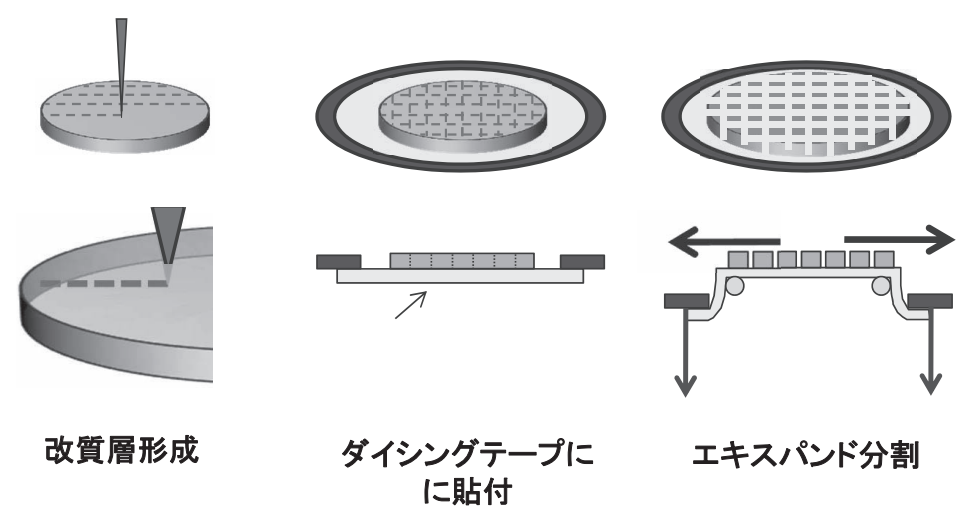

図12 ステルスダイシング

\section{チップ分割する方法である（図 12）. ステルスダイシング} の利点は

(1)チッピングやクラックが発生しにくく, 抗折強度の高 い高品位なチップが得られること.

(2)ダイシングライン幅が皆無に等しいこと.

(3)発塵が僅少であること.

ステルスダイシングではテープの拡張（エキスパンド）に よってチップ分割するため, ステルス用のダイシングテー プには等方的な引張特性が要求される.

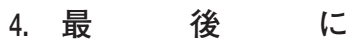

本稿ではICパッケージの高密度化にともなうウェハの 薄型化に対応したプロセスとダイシングテープの開発状況 を紹介した。高性能化やコストダウンといった課題は今な おダイシングテープに新たな問題解決を迫っており，成熟 感のあるダイシングテープではあるが，その実態は半導体 製造工程の絶え間ない技術革新に連動しながら半導体製造 の一端を担う材料として進化し続ける先端製品なのであ る.

\section{References}

1) Nagahiro, Y.: Nikkei Microdevices, 11, 37 (2009)

2 ) Ebe, K.; Narita, H.; Taguchi, K.; Akeda, Y.; Saito, T.: Jpn.
Tokkyo Koho 1712427 (1992)

3 ) Ebe, K.; Narita, H.; Taguchi, K.; Akeda, Y.; Saito, T.: Jpn. Tokkyo Koho 1603517 (1991)

4 ) Ebe, K.; Narita, H.; Taguchi, K.; Akeda, Y.; Saito, T.: Jpn. Tokkyo Koho 1638457 (1992)

5 ) Ebe, K.; Nagamoto, K.: Setchakunogijutsu, 21, (3) , 28 (2001)

6 ) Akiyama, M.; Okabe, T.: Setchakunogijutsu, 25, (1) ,6 (2001)

7 ) Takahashi, K.; Noguchi, H.; Ebe, K.: Jpn. Tokkyo Koho 3620810 (2004)

$8)$ Takyu, S.; Kurosawa, T.; Shimizu, N.; Harada, S.: Electronic Components and Technology Conference, 1623 (2006)

9 ) Inoue, K.: Laser focus World Japan, 9, 50 (2009)

10) Inoue, K.: Industrial Laser Solutions Japan, 7, 24 (2009)

11) Nagahiro, Y.: Nikkei Microdevices, 10, 38 (2009)

12) Sugiura, R.; Fukuyo, F,; Fukumitsu, K.; Uchiyama, N.: Laser Kako Gakkai Ronbunshu, 63, 115 (2005)

\section{日本語表記参考文献}

1 ）長廣恭明：日経マイクロデバイス，11, 37 (2009)

2 ) 江部和義, 成田博昭, 田口克久, 明田好孝, 斎藤隆則 : 特許 1712427 (1992)

3 ) 江部和義, 成田博昭, 田口克久, 明田好孝, 斎藤隆則：特許 160351 (1991)

4 ) 江部和義, 成田博昭, 田口克久, 明田好孝, 斎藤隆則：特許 1638457 (1992)

5 ）江部和義, 永元公市：接着の技術，21（3），28（2001）

6 ）秋山護，岡部年孝：接着の技術，25（1），6（2005）

7 ) 高橋和弘, 野口勇人, 江部和義 : 特許 3620810 (2004)

11）長廣恭明：日経マイクロデバイス，10, 38 (2009)

12）杉浦隆二, 福世文嗣, 福満憲志, 内山直己 : レーザ加工学会論 文集，63，115（2005） 